\title{
PENGARUH INTERNET FINANCIAL REPORTING DAN TINGKAT PENGUNGKAPAN INFORMASI MELALUI WEBSITE TERHADAP FREKUENSI PERDAGANGAN SAHAM PERUSAHAAN YANG TERDAFTAR DI INDEKS KOMPAS 100 PERIODE 2013-2017
}

\author{
${ }^{1}$ Hanifa Sri Nuryani, ${ }^{2}$ Reza Muhammad Rizqi, ${ }^{3}$ Nurul Apriani \\ ${ }^{1 *}$ Fakultas Ekonomi dan Bisnis Universitas Teknologi Sumbawa \\ 2Dosen Fakultas Ekonomi dan Bisnis Universitas Teknologi Sumbawa \\ 3Dosen Fakultas Ekonomi dan Bisnis Universitas Teknologi Sumbawa \\ 1*email: hanifatohri@gmail.com \\ 2 email: reza.muhammad.rizqi@uts.ac.id \\ 3email: nurulapriani67@gmail.com
}

\section{Diterima \\ Bulan Juli 2019 \\ Diterbitkan \\ Bulan Juli 2019}

Keywords:

Internet Financial Reporting,Tingkat pengungkapan Informasi melalui website, Frekuensi Perdagangan Saham

\begin{abstract}
Abstrak
This study aims to examine the effect of Internet Financial Reporting and the Level of Disclosure of Information Through Websites Against the Frequency of Stock Trading of Companies Listed in the Kompas 100 Index of 20132107. This research is quantitative research. The data collection method used in this study is the study of documentation on Indonesian Stock Exchange (Idx) facts in 2013-2017 to obtain stock trading frequency recapitulation during 2013-2017, literature study to collect data as a theoretical basis and observing websites to see website addresses company. The sampling technique uses purposive sampling. Data analysis used is multiple linear regression analysis. Based on the results of the study it can be concluded that Internet Financial Reporting affects the frequency of trading in company shares, and the level of disclosure of information through the website does not affect the frequency of trading in company shares. So, it can be said that companies that implement IFR have a higher frequency of trade than companies that do not implement IFR. While the level of website information disclosure is not enough to provide complete information to investors as the party who will assess the company's performance and prospects in the future and make decisions regarding investment.
\end{abstract}


Tahun 2017 ini penggunaan internet di Indonesia menjadi $54,68 \%$ dari seluruh penduduk Indonesia atau sekitar 143,26 juta pengguna, terjadi kenaikan penggunaan sebanyak 10,56 juta pengguna dibandingkan tahun 2016 atau naik sekitar 7\% (http:// www isparmo.web.id).

Adanya perkembangan internet, membuat perusahaan melaporkan laporan keuangannya melalui internet. Penggunaan internet ini menyebabkan pelaporan keuangan menjadi lebih cepat dan mudah, sehingga dapat diakses oleh siapa pun, kapan pun dan dimana pun. Selain itu, penyebarluasan informasi keuangan melalui internet dapat menarik investor dan memberikan image yang baik bagi perusahaan. Hal-hal inilah yang mendorong perusahaan-perusahaan untuk menerapkan praktik Internet Financial Reporting (IFR). Meskipun fenomena IFR berkembang pesat akhir-akhir ini, akan tetapi masih banyak juga perusahaan-perusahaan yang tidak melakukan praktik IFR (Sukanto, 2011). Perusahaan di Indonesia sebagian besar sudah menggunakan internet sebagai media komunikasi dalam menyajikan sebuah laporan keuangannya, akan tetapi banyak perusahaan belum secara optimal menerapkan informasi melalui internet dilihat dari website perusahaannya. Jones dan Xiao (2003) mengemukakan bahwa tidak semua perusahaan menyajikan laporan keuangan dalam website pribadi mereka. Hasil penelitian tentang IFR masih menghasilkan temuan yang tidak konsisten, sehingga perlu dilakukan pengujian lebih lanjut untuk mengetahui konsistensi temuan jika diterapkan pada kondisi lingkungan yang berbeda (Astarie, 2014).

Penelitian ini dilakukan pada perusahaan yang terdaftar di Indeks Kompas 100. Indeks Kompas 100 merupakan suatu Indeks saham yang terdiri dari 100 saham perusahaan publik yang diperdagangkan di Bursa Efek Indonesia. Indeks Kompas 100 diluncurkan oleh Bursa Efek Jakarta bekerjasama dengan Harian Kompas bertujuan untuk melengkapi berbagai acuan investasi yang telah ada bagi investor dan pelaku pasar modal. Saham-saham yang terpilih untuk dimasukkan dalam indeks Kompas 100 ini selain memiliki likuiditas yang tinggi serta nilai kapitalisasi yang besar, juga merupakan saham-saham yang memiliki fundamental dan kinerja yang baik. Dengan memiliki fundamental dan kinerja yang baik, pada umumya saham tersebut akan memiliki jumlah saham beredar dan harga saham yang sesuai (Elta dan Kamah, 2016).

Oyelere et al., (2003) memprediksikan bahwa IFR secara gradual akan mengambil alih peran pelaporan keuangan berbasis kertas. Pengungkapan informasi perusahaan melalui internet menarik perhatian institusi akuntansi dan juga para peneliti. Institusi akuntansi seperti International Accounting Standard Board (IASB),
International Accounting Standard Commitee (IASC), dan Financial Accounting Standard Board (FASB) telah meneliti akan status IFR dan menetapkannya sebagai salah satu pengungkapan sukarela perusahaan (corporate voluntary disclosure). IASC (1999) menerangkan bahwa penggunaan internet sebagai saluran penyajian dan pendistribusian laporan keuangan memiliki tiga tujuan, yaitu:

1. Perusahaan menggunakan internet hanya sebagai media untuk mennyebarkan laporan keuangannya yang telah dicetak dalam format digital seperti file dengan portable data file (PDF).

2. Perusahaan menggunakan internet untuk menyajikan laporan keuangan mereka dalam format web, yang memungkinkan mesin pencari membuat indeks atas data-data.

3. Perusahaan menggunakan internet tidak hanya sebagai media distribusi laporan keuangan, tetapi juga menyediakan cara yang lebih interaktif kepada pengguna. IFR digunakan untuk memudahkan pengguna dalam menilai posisi keuangan perusahaan. IFR dapat dikatakan berhasil apabila pengguna tersebut dapat merasakan kemudahannya dan kegunaan teknologi dari IFR. Adanya Internet Financial Reporting (IFR) dan pengungkapan informasi website, semua investor lebih mudah dan cepat dalam mengakses informasi yang dipublikasikan oleh suatu perusahaan sebagai pengambilan keputusan. Segala informasi tersebut membuat para investor berujung pada transaksi perdagangan saham sehingga terjadi penawaran dan permintaan oleh investor. Banyaknya jumlah suatu transaksi/ frekuensi perdagangan saham pada suatu periode menggambarkan likuiditas perdagangan saham atau bisa dikatakan semakin tinggi frekuensi perdagangan saham, semakin tinggi likuiditas perdagangan saham. Oleh sebab itu, tingginya likuiditas perdagangan saham maka investor semakin tertarik dan lebih diminati (Kumalasari et al., 2016).

Penelitian mengenai IFR sudah pernah dilakukan sebelumnya baik diluar negeri maupun di Indonesia ini. Di Indonesia keterimaan Internet Financial Reporting sebagai sebuah media komunikasi pernah diteliti oleh Rendi dan supatmi, (2013) dengan hasil bahwa publikasi laporan keuangan perusahaan berpengaruh positif pada volume perdagangan saham perusahaan.. Hasil penelitian menunjukan bahwa perusahaan yang menerapkan IFR dengan tingkat pengungkapan informasi yang tinggi cenderung mempunyai abnormal return yang lebih besar dan harga saham yang bergerak lebih cepat. Hal ini menunjukan adanya reaksi pasar (Investor) atas informasi yang diungkapkan di internet terhadap harga saham perusahaan, Perubahan harga saham dengan cepat merupakan indikasi dari kecepatan reaksi investor (Moduto, 2013). 
Berdasarkan hal tersebut maka peneliti tertarik melakukan penelitian mengenai pengaruh Internet Financial Reporting (IFR) dan pengungkapan informasi melalui website terhadap frekuensi perdagangan saham perusahaan.

Berdasarkan latar belakang masalah, adapun rumusan masalah adalah sebagai berikut :

1. Bagaimana pengaruh Internet Financial Reporting (IFR) terhadap frekuensi perdagangan saham perusahaan yang terdaftar di indeks kompas 100 ?

2. Bagaimana pengaruh tingkat pengungkapan informasi melalui website terhadap frekuensi perdagangan saham perusahaan yang terdaftar di indeks kompas 100 ?

\section{LANDASAN TEORI}

\section{Internet Financial Reporting (IFR)}

Internet Financial Reporting adalah suatu cara yang dilakukan perusahaan untuk mencantumkan informasi keuangannya melalui internet atau website yang dimiliki perusahaan (Ashbaugh et al., 1999). IFR disebut juga sebagai pengungkapan sukarela bukan karena isinya, tetapi dari media atau alat yang digunakan (Barac, 2004).

Menurut Ikatan Akuntan Indonesia (IAI, 2013) tujuan laporan keuangan adalah menyediakan informasi yang menyangkut posisi keuangan, kinerja, serta perubahan posisi keuangan suatu perusahaan yang bermanfaat bagi sejumlah besar pemakai dalam pengambilan keputusan. Investor suatu perusahaan bukan hanya di dalam negeri saja melainkan juga luar negeri. Kebutuhan pihak eksternal akan informasi keuangan perusahaan membuat tingkat kepentingan informasi keuangan meningkat. Salah satu cara perusahaan untuk menarik para investor luar negeri yaitu harus memiliki kualitas yang bagus dan bersaing dengan perusahaan lain baik dalam negeri maupun luar negeri dalam melaporkan informasi keuangan perusahaan melalui Internet Financial Reporting. Setiap negara memiliki kualitas Internet Financial Reporting yang berbeda dengan Negara lain dikarenakan setiap negara tidak memiliki standar atau aturan untuk perusahaan dalam melaksanakan pelaporan keuangan melalui internet. Semakin berkualitas informasi keuangan yang dilaporkan pada Internet Financial Reporting (IFR) semakin banyak pula investor yang tertarik untuk menanamkan modal pada perusahaan (Ema dan Luciana, 2013).

\footnotetext{
Tingkat Pengungkapan Informasi Melalui Website

Tingkat pengungkapan informasii melalui website pertama kali digunakan oleh Ettredge et al. (2002) untuk mengukur tipe pelaporan informasi yang ada dalam website perusahaan dengan
}

menggunakan item-item pengukurannya, yaitu berita terkini, informasi keuangan, dan informasi saham. Kemudian, Lai et al. (2010) mengadaptasi tingkat pengungkapan informasi melalui website ini dengan menambahkan dua tipe pelaporan informasi website perusahaan yang menerapkan IFR, yaitu profil dasar perusahaan dan item operasional. Tingkat pengungkapan informasi melalui website ini berguna untuk mengetahui kuantitas informasi yang ada dalam website perusahaan. Semakin tinggi tingkat pengungkapan informasi website perusahaan maka semakin besar dampak dari pengungkapan tersebut terhadap keputusan investor (Ashbaugh et al., 1999.

Melalui website perusahaan, maka pihak manapun akan dapat mengetahui dengan mudah mengenai informasi yang tercantum di dalamnya. Para investor dan kreditur dapat terbantu dalam membuat keputusan investasi dan keputusan bisnis lainnya dengan sistem pelaporan yang fleksibel dan memungkinkan mereka memperoleh informasi dengan cara yang lebih mudah, cepat dan berbiaya rendah. Hal ini dikarenakan internet menyediakan bentuk unik dari pengungkapan sukarela yang memungkinkan perusahaan memberikan informasi secara global sesegera mungkin (Abdelsalam, 2007).

\section{Frekuensi Perdagangan Saham}

Frekuensi perdagangan saham adalah jumlah transaksi perdagangan saham pada periode tertentu. Frekuensi perdagangan saham menggambarkan berapa kali suatu saham dari suatu emiten diperjualbelikan dalam suatu kurun waktu tertentu. Frekuensi perdagangan saham menggambarkan likuiditas perdagangan saham pada periode tertentu. Semakin tinggi frekuensi perdagangan saham, maka semakin tinggi likuiditas perdagangan saham tersebut. Tingginya likuiditas perdagangan saham menunjukkan bahwa saham tersebut semakin diminati oleh investor (Harsono, 2004).

\section{Kerangka Berfikir}

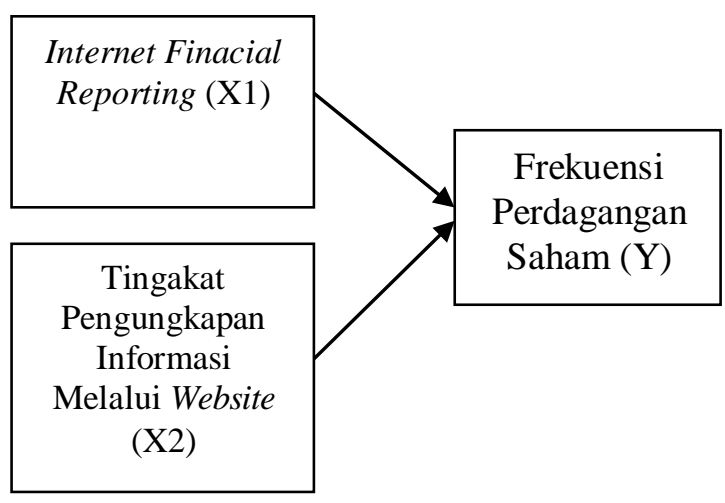

Gambar 2.1

Kerangka Berfikir 
Keterangan:

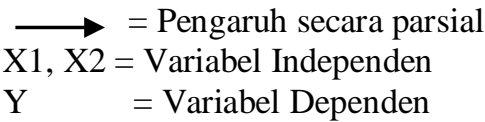

\section{HIPOTESIS PENELITIAN}

$\mathrm{H}_{1}$ : Internet Financial Reporting berpengaruh terhadap frekuensi perdagangan saham

$\mathrm{H}_{2}$ : Tingkat pengungkapan informasi melalui website berpengaruh terhadap frekuensi perdagangan saham

\section{DEFINISI OPERASIONAL}

Internet Financial Reporting (X1)

Pada variabel Internet Finacial Reporting Perusahaan yang menerapkan IFR dinilai "1" dan perusahaan yang tidak menerapkan IFR dinilai "0"(Sukanto, 2011).

\section{Perilaku keuangan (X2)}

Pada variabel tingkat pengungkapan informasi melalui website Pengukurannya menggunakan sistem skala 4 poin tertimbang untuk menilai setiap item informasi yang diungkapkan. Pengungkapan item informasi profil dasar perusahaan diberi poin 1 ; berita terbaru diberi poin 1 ; item operasional diberi poin 1; laporan keuangan singkat diberi poin 2; laporan keuangan tahunan lengkap diberi poin 3; laporan tahunan (annual report) dewan direksi diberi poin 4; dan informasi saham diberi poin 1 . Total poin berkisar antara 0 sampai 40 (Lai et al., 2010; Sukanto, 2011; dan Mooduto, 2013).

\section{Frekuensi Perdagangan Saham (Y)}

Pada Variabel frekuensi perdagangan saham mengacu pada data dari IDX Fact Book selama periode tahun 2013- 2017.

\section{METODE PENELITIAN}

Penelitian ini merupakan penelitian yang menggunakan pendekatan kuantitatif 1 . Pendekatan kuantitatif lebih menekankan pada pengujian teori melalui pengukuran variabel penelitian dengan angka dan melakukan analisis data dengan prosedur statistik.Metode dalam penelitian ini menggunakan penelitian kausal dengan tujuan untuk melihat adanya hubungan dan pengaruh antara variabel bebas dan variabel terikat (Sugiyono, 2010). Dalam penelitian ini penulis ingin mengetahui pengaruh Internet Financial Reportng dan tingkat pengungkapan infromasi melalui website sebagai variabel bebas terhadap Frekuensi perdagangan saham sebagai variabel terikat.

Populasi dalam penelitian ini yaitu perusahaan yang terdaftar di Indeks Kompas 100. Sampel dalam penelitian menggunakan jenis sampel non probabilitas.Metode penentuan sampel yang digunakan adalah purposive sampling yang dipiih berdasarkan kriteria-kriteria tertentu.

1). Yang terdaftar dalam indeks kompas 100 dan memiliki data historis yang lengkap peiode 20132017.

2). Memiliki situs web perusahaan pribadi yang tidak dalam kondisi maintenance

3). Menerapkan praktek Internet Finacial Reporting dan tidak menerapkan praktek Internet Financial Reporting (IFR).

Kemudian diperoleh jumlah sampel sebanyak 91 sampel.

Metode pengumpulan data dalam penelitian ini adalah studi dokumentasi, studi pustaka, dan observasi. .Jenis data yang digunakan adalah data sekunder.

\section{Teknik Analisis Data}

Metode analisis yang digunakan dalam penelitian ini adalah regresi linear berganda menggunakan software Statistical Package for Social Science (SPSS).Teknik analisis data dalam penelitian ini adalah dengan menggunakan uji asumsi klasik dan uji hipotesis.

\section{HASIL DAN PEMBAHASAN}

\section{Uji Asumsi Klasik}

1. Uji Normalitas

Table 4.3. Hasil Uji Normalitas

\begin{tabular}{|l|l|r|}
\hline \multicolumn{2}{|c|}{ One-Sample Kolmogorov-Smirnov Test } \\
\hline \multirow{2}{|l|}{} & $\begin{array}{c}\text { SQRFRE } \\
\text { K }\end{array}$ \\
\hline $\mathrm{N}$ & Mean & 91 \\
\hline $\begin{array}{l}\text { Normal } \\
\text { Parameters }\end{array}$ & Std. Deviation & $\begin{array}{r}5.920215 \\
88 \mathrm{E} 2\end{array}$ \\
\cline { 2 - 3 } & & .0000000 \\
\hline $\begin{array}{l}\text { Most Extreme } \\
\text { Differences }\end{array}$ & Absolute & .045 \\
\cline { 2 - 3 } & Positive & -.046 \\
\cline { 2 - 3 } & Negative & .444 \\
\hline Kolmogorov-Smirnov Z & .989 \\
\hline Asymp. Sig. (2-tailed) & \\
\hline a. Test distribution is Normal. & \\
\hline
\end{tabular}

Sumber :Output SPSS datadiolah peneliti, 2019

Berdasarkan table 4.3. hasil uji normalitas diperoleh Asymp. Sig (2-Tailed) sebesar 0,989 atau diatas 0,05. Dengan demikian data pada variabel tersebut disimpulkan berdistribusi normal. 


\section{Uji Multikolinearitas}

Tabel 4.4. Hasil Uji Multikolinearitas

\begin{tabular}{|l|r|l|l|}
\hline Variabel & Tolerance & VIF & Keterangan \\
\hline $\begin{array}{l}\text { Internet } \\
\text { Financial } \\
\text { Reporting }\end{array}$ & .431 & $\mathbf{2 . 3 1 8}$ & $\begin{array}{l}\text { Tidak terjadi } \\
\text { Multikolinearitas }\end{array}$ \\
\hline $\begin{array}{l}\text { Tingkat } \\
\text { pengungkapan } \\
\text { infromasi } \\
\text { melalui } \\
\text { website }\end{array}$ & .431 & $\mathbf{2 . 3 1 8}$ & $\begin{array}{l}\text { Tidak terjadi } \\
\text { Multikolinearitas }\end{array}$ \\
\hline
\end{tabular}

Sumber :Output SPSS datadiolah peneliti, 2019

Berdasarkan Tabel 4.4. menunjukkan bahwa semua variabel bebas nilai Tolerance dari masing-masing variabel lebih besar dari 0.1 dan VIF lebih kecil dari 10 maka disimpulkan bahwa dari seluruh variabel bebas dalam penelitian ini tidak terjadi multikolinearitas.

\section{Uji Autokorelasi}

Tabel 4.5. Hasil Uji Autokorelasi

\begin{tabular}{|l|c|c|c|c|c|}
\hline \multicolumn{7}{|c|}{ Model Summary } \\
o & R & R & Adjust & Std. & Durbin \\
de & & Squ & ed R & Error & - \\
are & Square & $\begin{array}{c}\text { of the } \\
\text { Watso }\end{array}$ \\
& & & & $\begin{array}{r}\text { Estima } \\
\text { te }\end{array}$ & \\
\hline 1 & .200 & .040 & .018 & 598.71 & 2.156 \\
& & & 1310 & \\
\hline
\end{tabular}

Sumber :Output SPSS datadiolah peneliti, 2019

Berdasarkan Tabel 4.5. menunjukkan bahwa Berdasarkan hasil uji Durbin-Watson di atas diperoleh nilai Durbin-Watson (d) $=2,156$. Penelitian ini menggunakan dua variabel independen dengan jumlah sampel sebanyak 91 . Oleh karena itu, berdasarkan tabel Durbin-Watson diperoleh nilai batas bawah $(\mathrm{dL})=1,5915$ dan batas atas $(\mathrm{dU})=1,7275$. Kesimpulannya, $\mathrm{du}<\mathrm{d}<4$-du $=$
$1,7275<2,156<2,2725$. Artinya, tidak terdapat autokorelasi positif maupun negatif, karena nilai (d) yaitu lebih besar dari nilai (dU) yaitu 1,7275dan kurang dari nilai (4-dU) yaitu 2,2725.

\section{Uji Heterokedastisitas}

Tabel 4.6. Hasil Uji Heterokedastisitas

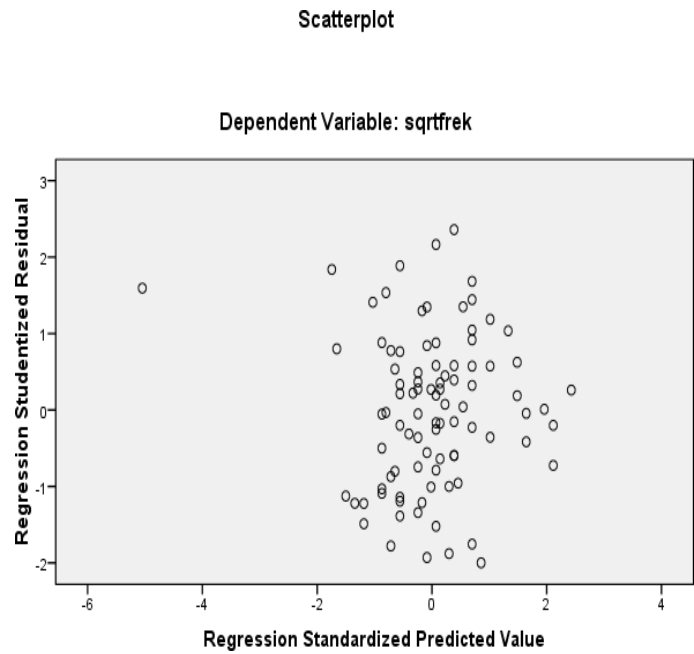

Sumber :Output SPSS datadiolah peneliti, 2019

Berdasarkan tabel 4.6 diaatas menunjukan titik-titik tidak membentuk pola tertentu dan titiktitik tidak menyebar di atas dan di bawah angka nol pada sumbu Y, sehingga dapat disimpulkan tidak terjadi heterokedastisitas dalam model regresi, sehingga asumsi non heterokedastisitas terpenuhi.

\section{Hasil Analisis Regresi Linear Berganda}

Persamaan yang digunakan dalam penelitian ini adalah sebagai berikut :

$$
Y=\alpha+B 1 X 1+B 2 X 2+\varepsilon i t
$$

Tabel 4.7. Hasil Analisis Regresi Linear

\begin{tabular}{|c|c|c|c|}
\hline \multirow[b]{2}{*}{ Model } & \multicolumn{2}{|c|}{$\begin{array}{c}\text { Unstandardized } \\
\text { Coefficients }\end{array}$} & \begin{tabular}{|c} 
Standardi \\
zed \\
Coefficie \\
nts
\end{tabular} \\
\hline & B & Std. Error & Beta \\
\hline $1 \quad$ (Constant) & 1446.351 & 174.292 & \\
\hline IFR (X1) & 409.7719 & 239.896 & .272 \\
\hline INFO (X2) & -19.012 & 10.229 & -.292 \\
\hline
\end{tabular}

a. Dependent Variable: SQRTFREK(Y) 
Sumber :Output SPSS datadiolah peneliti, 2019 $Y=144,351+409,771 X 1-19,012 X 2+$ eit

1. Hasil daripada nilai konstanta dari regresi di atas sebesar 1446,351. Artinya, apabila nilai variabel independen yaitu Internet Financial Reporting (IFR) dan tingkat pengungkapan informasi website (INFO) bernilai 0 , maka nilai variabel dependen yaitu frekuensi perdagangan saham (SQRTFREK) adalah1445,351.

2. Hasil koefisien regresi Internet Financial Reporting (IFR) pada hasil regresi di atas adalah 409,771. Artinya perubahan yang terjadi sebesar 1 satuan akan mengakibatkan penurunan frekuensi perdagangan saham (SQRTFREK) sebesar 409,771.

3. Hasil koefisien regresi tingkat pengungkapan informasi website (INFO) adalah -19,012. Artinya, bila terjadi perubahan tingkat pengungkapan informasi website (INFO) sebesar 1 satuan, maka akan memberikan dampak penururnan frekuensi perdagangan saham (SQRTFREK) sebesar -19,012.

\section{Uji Hipotesis \\ 1. Uji T}

Tabel 4.8. Hasil Uji T

\section{Coefficients}

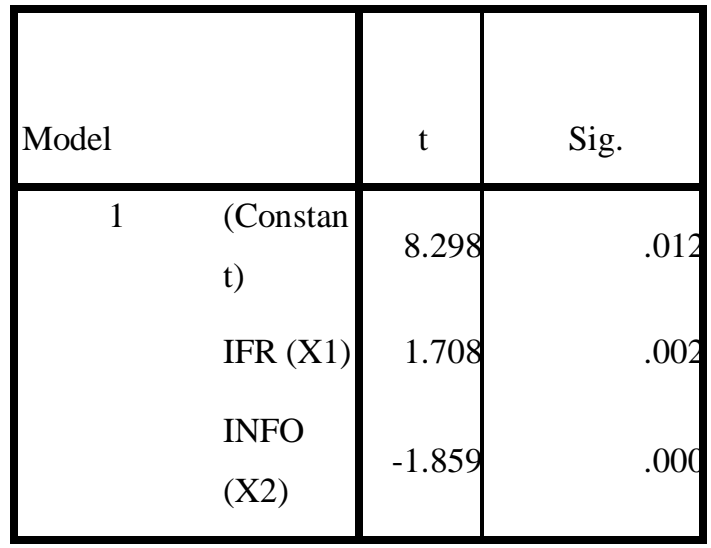

a. Dependent Variable: SQRTFREK (Y)

Sumber :Output SPSS datadiolah peneliti, 2019

Hasil pengujian yang telah dilakukan di atas menunjukkan bahwa :

1.Internet Financial Reporting terhadap frekuensi perdagangan saham perusahaan yang terdaftar Indeks Kompas 100

Berdasarkan hasil uji regresi linear berganda nilai $t_{\text {hitung }}$ sebesar 1,708 $>\mathrm{t}_{\text {tabel }}$ sebesar 1.661, maka dapat disimpulkan bahwa $\mathrm{H} 1$ atau hipotesis pertama diterima artinya adanya pengaruh Internet Finacial Reporting terhadap frekuensi perdagangan saham dan tingkat signifkansi $(\alpha)$ $0,002<0,05$ artinya Internet Financial Reporting berpengaruh signifikan terhadap frekuensi perdagangan saham. Dengan kata lain bahwa adanya Internet Financial Reporting berpengaruh terhadap frekuensi perdagangan saham perusahaan pada perusahaan yang terdaftar di indeks kompas 100 tahun 2013-2017.

Hal ini senada dengan yang diungkapkan oleh Lai et al., (2010) dan Fama et. al., (1969) yaitu saham akan bergerak ketika informasi yang berguna memasuki pasar. Tiap pengungkapan informasi akan membuat investor memeriksa kembali penilaian mereka terhadap nilai saham dan membuat keputusan untuk menjual atau untuk memegang saham. Lebih lanjut, informasi yang diungkapkan melalui IFR secara cepat tersedia bagi semua investor sehingga asimetri informasi akan berkurang dan memperpendek delay aksesibilitas informasi.

Jadi, bisa dikatakan perusahaan yang menerapkan IFR akan mempunyai harga saham yang responsive sehingga mempunyai frekuensi perdagangan yang lebih tinggi dibanding perusahaan yang tidak menerapkan IFR. Hal ini dikarenakan informasi yang berguna bagi investor dapat dipublikasikan dengan lebih cepat.

2. Tingkat pengungkapan infromasi melalui website terhadap frekuensi perdagangan saham

Berdasarkan hasil uji regresi linear berganda bahwa nilai $t_{\text {hitung }}$ sebesar $-1,859<t_{\text {tabel }}$ sebesar 1.661 maka dapat disimpulkan bahwa $\mathrm{H} 2$ atau hipotesis kedua ditolak artinya tidak adanya pengaruh tingkat pengungkapan informasi melalui website terhadap frekuensi perdagangan saham dan tingkat signifkansi $(\alpha) 0,000<0,05$ artinya tingkat pengungkapan informasi melalui website berpengaruh signifikan terhadap frekuensi perdagangan saham. Dengan kata lain bahwa ada atau tidaknya tingkat pengungkapan infromasi melalui website tidak berpengaruh terhadap frekuensi perdagangan saham perusahaan yang terdaftar di Indeks Komaps 100 tahun 2013-2017.

Hal ini senada yang diungkapkan oleh penelitian yang dilakukan Elta dan Kamal, 2016 yang dimana tingkat pengungkapan informasi melalui website tidak berpengaruh terhadap frekuensi perdagangan saham.

Transaksi perdagangan jual ataupun beli saham pada perusahaan yang terdaftar di Indeks Kompas 100 tidak dipengaruhi oleh tingkat pengungkapan informasi website yang dilakukan oleh perusahaan yang terdaftar di Indeks Kompas 100 tersebut. Hal ini disebabkan karena tingkat pengungkapan informasi website yang dilakukan oleh perusahaan yang terdaftar di Indeks Kompas 100 tidak cukup memberikan informasi yang lengkap kepada pihak investor selaku pihak yang akan menilai kinerja dan prospek perusahaan tersebut dimasa mendatang serta mengambil keputusan yang berkenaan dengan investasi. Oleh karena itu, tingkat pengungkapan informasi website 
tidak memiliki pengaruh terhadap frekuensi perdagangan saham perusahaan yang terdaftar di Indeks Kompas 100.

\section{Koefisien Determinasi}

Tabel.4.9. hasil Uji koefisien determinasi

\begin{tabular}{|l|c|c|c|c|}
\hline \multicolumn{5}{|c|}{ Model Summary } \\
el & & R & Adju & Std. \\
& & re & R \\
sted & Error of \\
the \\
\end{tabular}

Sumber :Output SPSS datadiolah peneliti, 2019

Berdasarkan nilai koefisien determinasi yang ditunjukkan pada Tabel 4.9 dengan nilai $\mathrm{R}$ Square adalah 0.040. Hasil ini menunjukkan bahwa pengaruh Internet Financial Reporting dan Tingkat pengungkpana informasi melalui website terhadap frekuensi perdagangan saham sebesar 4\% dan sisanya $96 \%$ dipengaruhi oleh variabel lain di luar model dalam penelitian ini seperti jumlah saham beredar, ukuran perusahaan, dan volume perdagangan. Adjusted $R^{2}$ dalah nilai $\mathrm{R}$ Square yang telah disesuaikan, nilai ini selalu lebih kecil dari R Square. Pada Tabel 4.9 terlihat bahwa nilai Adjusted $R^{2}$ sebesar 0.018. Nilai Adjusted $R^{2}$ dapat naik atau turun berdasarkan signifikasi variabel independen. Adjusted $R^{2}$ dapat bernilai negatif, sehingga jika nilainya negatif, maka nilai tersebut di anggap 0 atau variabel bebas sama sekali tidak mampu menjelaskan varian dari variabel terikat.

\section{PENUTUP}

\section{Kesimpulan}

Sampel dalam penelitian ini adalah perusahaan yang masuk dalam Indeks Kompas100 yang berjumlah 91 perusahaaan. Berdasarkan analisis data dan pembahasan yang telah dilakukan, maka dapat diambil kesimpulan, antara lain :
1. Internet Financial Reporting

berpengaruh positif dan signifikan terhadap frekuensi perdagangan saham perusahaan. Artinya, terdapat pengaruh Internet Finacial Reporting (IFR) terhadap frekuensi perdagangan saham perusahaan yang terdaftar di Indeks Kompas 100.

2. Tingkat pengungkapan informasi melalui website berpengaruh negative dan signifikan terhadap frekuensi perdagangan saham perusahaan. Artinya tidak terdapat pengaruh tingkat pengungkapan informasi melalui website terhadap frekuensi saham perusahaan yang terdaftar di Indeks Kompas 100.

\section{SARAN}

a. Bagi Peneliti Selanjutnya

Bagi peneliti selanjutnya disarankan untuk melakukan penelitian pada perusahaan dengan sektor lain untuk melihat bagaiman pengaruh Internet Financial Reporting dam tingkat pengungkapan informasi website terhadap frekuensi perdagangan saham perusahaan di sektor lainnya. Selain itu peneliti selanjutnya juga dapat melakukan penelitian dengan variabel independen yang serupa namun terhadap volume perdagangan saham perusahaan.

\section{b. Bagi Tempat Akademis}

Bagi pihak akademis lebih memahami Internet Financial Reporting, tingkat pengungkapan informasi melalui website dan pengaruhnya terhadap frekuensi perdagangan saham.

\section{REFERENSI}

Abdelsalam, O.H., S. M., Bryant, dan D. L. Street.(2007).An Examination of the Comprehensiveness of Corporate Internet Reporting Provided b London- Listed Companies.Journal of International Accounting Research.Vol. 6, No.2, 1- 33 .

Abdelsalam, O.H., El-Masry, Ahmed.(2008).The Impact Of Board Independence And Ownership Structure On The Timeliness Of Corporate Internet Reporting Of Irish-Listed Companies.Managerial Finance. Volume 34 Nomor 12, 907-918.

APJII2015: Indonesia Internet Users.Laporan Asosiasi Penyelenggara Jasa Internet Indonesia.(2015).Diakse pada 5Januari 2019, dari:http://www.apjii.or.id/v2/read/ 
page/halamandata/9/statistik.html.Kutipan: APJII 2015( 2019)

Asbaugh, H., Johnstone, K., and Warfield, T. (1999).Corporate Reporting on theInternet.Accounting Horizons. Vol.13, 241-257.

Astari, Farida Noviana.(2014).Faktor penentu Internet Financial Reporting dan Pengaruhnya Terhadap Frekuensi Perdagangan Saham. Artikel Manajemenkeuangan.,pp1-11.

Ball, R.(2006). Internasional Financial Reporting Standarss (IFRS): Pros and Cons for Investors.Accounting and Business Research. Vol.36, 5-27.

Barac, K.(2004). Financial Reporting on the Internet in South Africa.Meditari Accountancy Research.Vol.12(1),120.

Damayanti, Kartika dan Supatmi.(2012).Internet Financial Reporting (IFR) Dan ReaksiPasar.Jurnal Ekonomi dan Bisnis. Vol 14, 613-625.

Elta,L and M.kamah.(2016).Pengaruh jumlah saham beredar, ifr, tingkat pengungkapa ninformasi website dan harga saham penutupan terhadap frekuensi perdagangan saham perusahaan", journal of management. Vol.4, 1-9.

Ettredge, M., V. J. Richardson, and S. Scholz.(2002). Dissemination of Information for Investors at Corporate Web sites.Journal ofAccounting and Public Policy.Vol.21, 357- 369.

Ghozali, Imam. (2011). Aplikasi Analisis Multivariate dengan Program SPSS.Semarang:

UniversitasDiponegoro.

Ghozali, Imam.(2016).Aplikasi Analisis Multivariate dengan program IBM SPSS 23.Semarang: Badan Penerbit Universitas Di Ponegoro.

Handayani, Emma dan L.S Almilia.(2013). Internet Financial Reporting: studi komparasi Perusahaan manufaktur yang terdaftar Di bursa efek indonesiadan bursa efek malaysia .Jurnal Bisnis dan ekonomi. Vol.20,No.2,100-112.

Gray, S.,J., dan Roberts, C.B.(1989). Voluntary Information Disclosure Policy and the Informationess of Stock Price.Seton Hall University and New York University: Working Paper.

Hanafi, Mamduh.(2005). Manajemen Keuangan. Yogyakarta: BPFE Yogyakarta.

Hanafi, Mamduh. (2014). Manajemen Keuangan, Edisi Kesatu.Yogyakarta: BPFE.

Harsono, Margaretha K.(2004). Analisis Pemecahan Saham: Dampak terhadap Likuiditas Perdagangan dan Pendapatan Saham. Balance. Vol.1,No.1,73 - 86.

Ikatan Akutantan Indonesia(2013): Exposure Draft Pernyataan Standar Akutansi Keuangan, Penyajian Laporan Keuangan(2013). Diakses tanngal 8 Juli 2019 dari: https://staff.blog.ui.ac.id.Kutipan: IAI 2013(2019)

IASCInternational acoounting Standars.(1999).The Conceptual Framework for Finacial Reporting. U.K:Londom

IDX-Fact Book 2013-2017.Rekapitulasi Frekuensi Perdagangan Saham Perusahaan..Available online at: www.idx.co.id/factbook2013-2017.

Isparmo(2018): Data Statistik Penggunaaan Internet di Indonesia 2017 BerdasarkanHasil Survey APJJI. diakeses 10 januari 2019, dari:http://www.isparmo.web.id/2018 /08/01/data-statistik-penggunainternet-di-indonesia-2017berdasarkan-survey-apjii/. Kutipan: Isparmo 2018(2019).

Jensen,C.M. (2001). Value Maximization, Stakeholder Theory, And The Corporate Objective Function. Journal of Applied Corporate Finance, Morgan Stanley,.vol. 14(3), 8-21.

Juliandi ,Azuar dan Irfan.(2014). Metodologi Penelitian Kuantitatif untukIlmu- 
Ilmu Bisnis. Bandung:Cita pustaka Media Perintis.

Jogiyanto.(2000).Teori Portofolio dan Analisis Investasi.Yogyakarta:BPFE.

Jones, M.J and J.Z Xiao.(2003).Internet Reporting: Current Trends by 2010.Feature Article. Vol.8,132-145.

Jones, Charles P. (2002). Investment analysis and management (8th ed). England: John Willey \&DonsInc.

Kumalasari,C., A.W.S Gama. I.W Suarjana.(2016).Pengaruh Internet Financial Reporting dan tingkat pengungkapan informasi website terhadap frekuensi perdagangan sahamperusahaan. Journal of economy.Vol.13,pp.1-10.

Lai,et al.,.(2009). An Empirical Study of the Impact of Internet Financial Reporting on Stock Prices.International journal of digital accounting research. Vol. 10 No. 16, 35-65.

Lai et al.,.(2010).An Empirical Study of the Impact of Internet Financial Reporting on Stock Prices.The International Journal of Digital Accounting Research . Vol. $10,20-10$.

Manullang et al.,.(2014).Pengaruh Internet Financial Reporting dan Tingkat Pengungkapan Informasi Website Terhadap Frekuensi Perdagangan Saham Perusahaan (Studipada Perusahaan Pertambangan yang Terdaftar di Bursa Efek Indonesia Tahun 2010-2013).Jurnal manajemen keuangan.Vol.2 No. 1,4-28.

Moduto, W.I.(2013).Reaksi Investor atas Pengungkapan Internet Financial Reporting .Jurnal Review Akutansi dan Keuangan. Vol.3 no. 2,479-491

Oyelere, P., F. Laswad and R. Fisher.(2003). Determinants of Internet Financial Reporting by NewZealand Companies. Journal of International Financial management and Accounting. Vol.7,26-62.

Pirchegger, B \&Wagenhofer, A.,.(1999).Financial Information on The Internet: A Survey of the Homepages of AustrianCompanies. The European acoounting Review. Vol.8, 383-395.

Priyanto, D.(2016).PSS Handbook: Analisis Data, Olah Data \& Penyelesaian KasusKasusStatistik. Yogyakarta : Mediakom.

Sahamok2019: Kriteria Pemilihan Saham Indek Kompas 100 (2019). Di akses 25 maret 2019 dari: http://www.sahamok.com/bei/indeksbursa/indeks-kompas-100. Kutipan: Saham oke 2019(2019).

Sari, Ratna Candra dan Zuhrotun.(2006). Keinformatifan Laba di Pasar Obligasi dan Saham, Uji Liquidation Option Hypothesis.Padang: Simposium Nasional

Satria, Redi Dan Supatmi. 2013.Reaksi Pasar Sebelum Dan Sesudah Internet Financial Reporting. Jurnal Akutansi Dan Keuangan .Fakultas Ekonomi dan Bisnis Universitas Kristen Satya Wacana.Vol. 15.No. 2.Pp 86-94.

Savitri, Sheila.(2016). Peranan Internet Sebagai Sumber Informasi.Jakarta: Balai Pengkajian Teknologi pertanian.

Sugiyono.(2009). Metode Penelitian Bisnis. Bandung: Alfabeta

Sugiyono.(2010). Metode Penelitian Pendidikan Pendekatan Kuantitatif. Bandung: Alfabeta.

Sukanto, Eman.(2011).Pengaruh Internet Financial Reporting dan Tingkat Pengungkapan Informasi Website Terhadap Frekuensi Perdagangan Saham Perusahaan di Bursa.FokusEkonomi. Vol. 6 No. 2, 80-98.

Sulistyanto, Sri.(2008). Manajemen Laba (Teoridan Model Empiris).Jakarta: Grasindo.

Wikepedia2019: Indeks kompas 100 (2019). Diakses $22 \quad$ maret 2019 dari:http://id.m.wikepedia.org/wiki/ind eks kompas100.Kutipan: Wikipedia 2019 (2019) 